\title{
STRUCTURES OF Heracleum sosnovskii Manden. STEM AND LEAVES RELEASING PHOTODERMATOSIS-CAUSING SUBSTANCES
}

\author{
Elżbieta Weryszko-Chmielewska, Mirosława Chwil
}

\author{
Department of Botany, University of Life Sciences in Lublin \\ Akademicka 15, 20-950 Lublin, Poland \\ e-mail: elzbieta.weryszko@up.lublin.pl
}

Received: 11.08.2014

\section{Abstract}

In its stems and leaves, Heracleum sosnovskii Manden. contains furanocoumarins, which exert a phototoxic effect on humans. The aim of the investigations was to describe the external secretory structures of the epidermis and internal secretory tissues in organs responsible for emission of secretion that is toxic to human skin. The study was conducted using light and fluorescence microscopy. On the stems and leaves, various types of secretory trichomes with dispersed or deposited secretion were found. The trichomes were most abundant on the abaxial leaf surface. Epidermal cells and the secretion present on the trichomes exhibited intense fluorescence, which may indicate the presence of furanocoumarins in the tissue and trichome secretions.

Key words: Heracleum sosnovskii, stem, leaves, epidermis, glandular trichomes, photodermatosis

\section{INTRODUCTION}

Heracleum sosnovskii Manden (Heracleum sosnowskyi Manden.) from the family Apiaceae originates from the Caucasus and adjacent regions. In Poland, the species was introduced into cultivation in the seventies and eighties of the $20^{\text {th }}$ century as a fodder and nectariferous plant $[1,2]$. Due to the unpleasant odour of milk and meat of animals that were fed with the fodder as well as photodermatoses diagnosed in workers who collected the plant, cultivation thereof was abandoned [3]. However, in the Caucasus region, fresh or marinated young shoots and leaves of H. sosnovskii are consumed by humans. They can also be added to soup [1]. The phototoxic activity has also been detected in other Heracleum species containing furanocoumarins [4-7].
As a plant that is becoming wild, $H$. sosnovskii has spread spontaneously in many regions of Poland, e.g. in Małopolska and the Vistula River valley [8-11]. Currently, the species is classified as a naturalised invasive plant in Poland [12, 2].

H. sosnovskii is a biennial or perennial plant reaching a height of $3-5 \mathrm{~m}[7,13]$. Its stem is deeply grooved and covered with not very dense burning trichomes [1]. The characteristics of the epidermal secretory trichomes in $H$. mantegazzianum and H. sphondylium were presented by A r o r a et al. [14]. The different types of trichomes covering the epidermis of aboveground organs in 16 species of the genus Heracleum have been regarded as key traits in plant taxonomy [15]. The presence of coumarin compounds and essential oils produced in secretory tissues is a characteristic feature of the plants from the genus Heracleum [16].

We have found no literature data on the structure of $H$. sosnovskii tissues that secrete substances triggering phototoxic reactions. The aim of the paper was to conduct preliminary analysis of exogenous and endogenous $H$. sosnovskii secretory tissues, which release phototoxic substances. The investigations were carried out using light and fluorescence microscopy.

\section{MATERIALS AND METHODS}

Analyses of the Heracleum sosnovskii Manden. stems and leaves were conducted. Fragments of the organs were sampled from plants growing in the Botanical Garden of Maria Curie-Skłodowska University in Lublin. The secretory tissues were observed under a light (LM) and fluorescence (FM) microscopes. 


\section{Stereoscopic microscopy}

A stereoscopic microscope equipped with a NICON COOLPIX 4500 photographic camera was used for comparative observations of the trichomes on the epidermis surface in the examined organs.

\section{Light microscopy}

In order to identify the secretory structures involved in exo- and endosecretion in the analysed species, hand-cut cross-sections of stems, leaf blades, and petioles were made. The sections were stained with Lugol's solution. Observations of active secretory cells were performed using a Nicon Eclipse $600 \mathrm{mi}-$ croscope.

The length of trichomes on the abaxial epidermis of the leaf blades and petiole epidermis was measured. Morphometric measurements of the trichomes were performed using a computer program for analysis of the microscopic image Nikon NIS-Elements version 3.0 Advance Research.

\section{Fluorescence microscopy}

Hand-made sections of fresh fragments of leaf blades and petioles were placed in $0,01 \%$ auramine $\mathrm{O}$ (Wędzony 1996). The secretory structures were observed under a fluorescence microscope Nikon Eclipse 90i equipped with a FITC filter (excitation light $465-495 \mathrm{~nm})$, a DAPI filter (340-380 nm), and a barrier filter (wavelength $515-555 \mathrm{~nm}$ ).

\section{RESULTS}

The surface of all the examined $H$. sosnovskii organs, i.e. stems, leaf blades, and petioles, exhibited unicellular secretory trichomes with varied length. The trichomes on the petioles were longer $(150-3850 \mu \mathrm{m})$ than those on the leaf blades (111-677 $\mu \mathrm{m})$. They had a pointed apex and, most frequently, granular surface ornamentation (Fig. 1 A-C, G, I). Shorter petiole trichomes reached a length of 150-627 $\mu \mathrm{m}$ and those on the abaxial surface of the lamina were 111-222 $\mu \mathrm{m}$ long. The trichomes were rounded or pointed at the apex (Fig. 1 D-F, J).

The stem epidermis was dominated by longer, unevenly distributed trichomes. Besides pubescent areas, some fragments devoid of trichomes were visible. The petioles had characteristic ribs covered by larger trichome clusters than those on the other parts of the epidermis of the organs. The adaxial surface of the leaf blades exhibited only short trichomes distributed primarily on the edges. In turn, the abaxial leaf blade surface was characterised by occurrence of various types of trichomes distributed more densely along the veins.

Both large and small trichomes contained viable protoplasts. Crystalline structures, possibly secretions, were visible on the outer surface of the cell walls of many trichomes (Fig. $1 \mathrm{C}, \mathrm{H}, \mathrm{I}-\mathrm{K}$ ). A foamy substance was observed at the apex of some trichomes (Fig. 1G). The leaf blades and petioles had trichomes with a smooth wall in addition to those with outer cell wall ornamentation (Fig. 2 A, B).

The analysis performed using the fluorescence microscope revealed differences in the fluorescence of the stem and leaf tissues, depending on the filter used. The DAPI filter showed blue fluorescence of the cuticle (Fig. 3 A) and the walls of some cells as well as a substance deposited on the trichome surface (Fig. $3 \mathrm{H}$ ). When the FITC filter was used, green fluorescence was visible in the case of the epidermal cells of the petiole, leaf veins, and leaf blade (Fig. 3 B-F) as well as secretion deposited beside or on the surface of the trichomes (Fig. 3 B, G).

Two types of secretory structures, i.e. trichomes (Fig. 2C) and secretory channels (Fig. 2 D-F), were visible in the $H$. sosnovskii stems. Cross-sections of the stems showed greenish droplets of essential oil released through the channels (Fig. 2 E). The secretion contained in the cells of the secretory channel epithelium emitted relatively strong fluorescence as well (Fig. 3 A). 

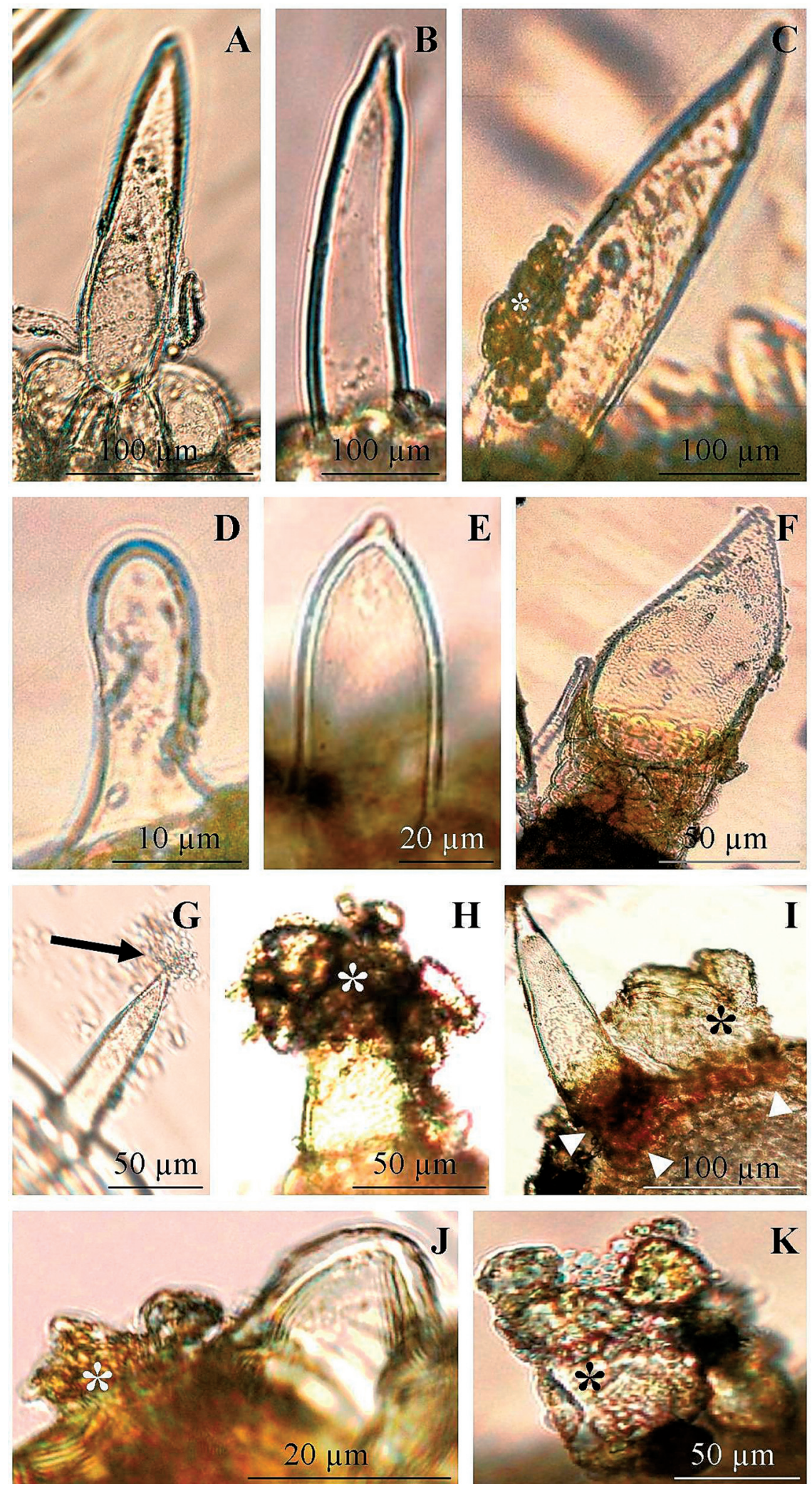

Fig. 1 A-K. Different types of trichomes on the surface of a H. sosnovskii leaf after treatment with Lugol's solution: A-C - unicellular, elongated trichomes, visible secretions (asterisk) on the surface of the trichome, D-F - short, rounded or apically pointed trichomes,

G-K - foamy (arrow) or crystalline (asterisk) secretion at the apex or base of the trichome, visible intensely stained cells (arrowhead) of the epidermis and the trichome base. 

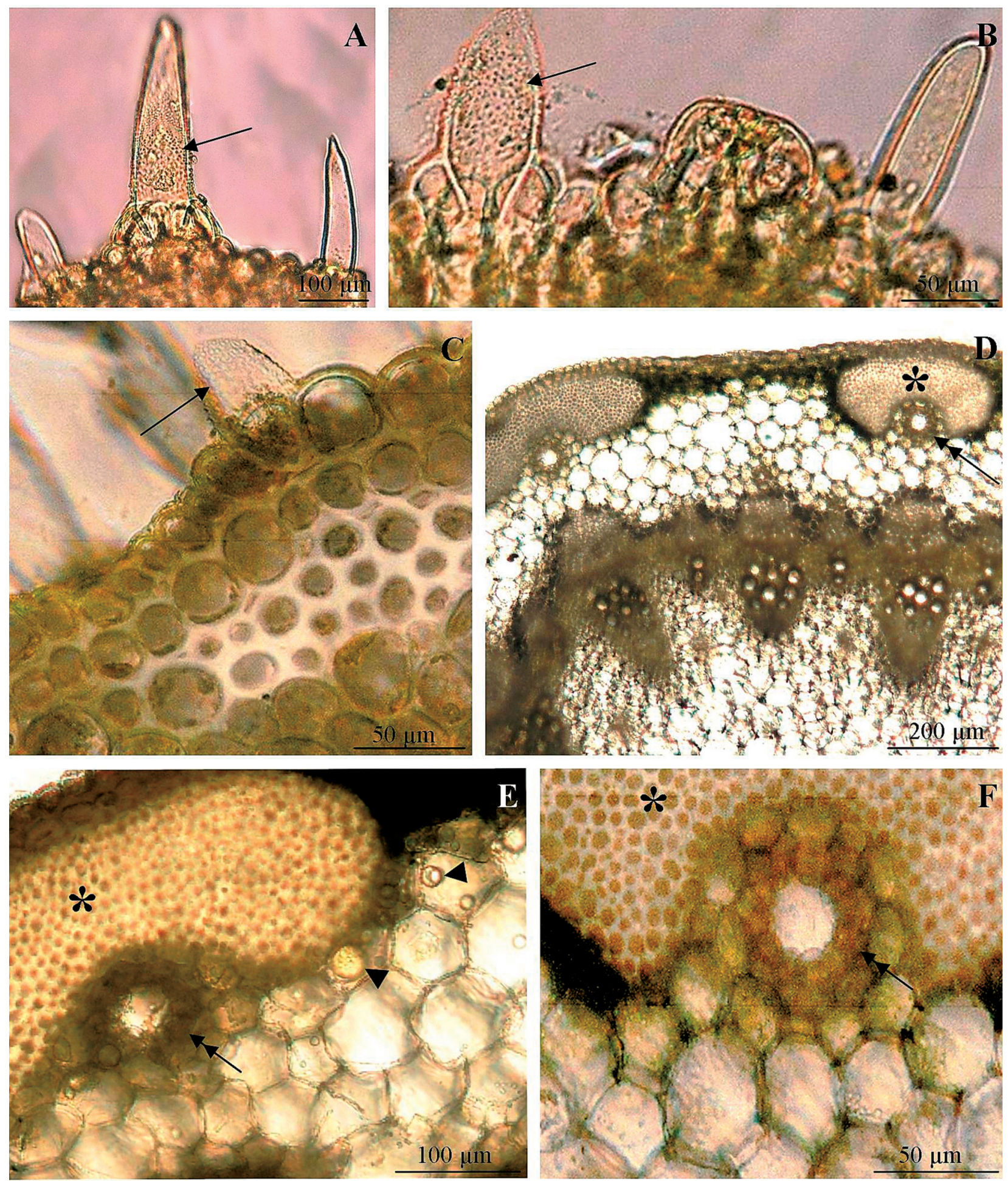

Fig. 2 A-F. Fragments of $H$. sosnovskii leaves (A - B) and stems (C-F) after treatment with Lugol's solution (cross section):

A-C - trichomes on the abaxial leaf epidermis (A, B) and on the surface of stem, some with granular cell wall ornamentation (arrow),

D-F - oil ducts with secretory epithelial cells (arrow with a double arrowhead), visible drops of essential oil (arrowhead), and a collenchyma layer (asterisk). 

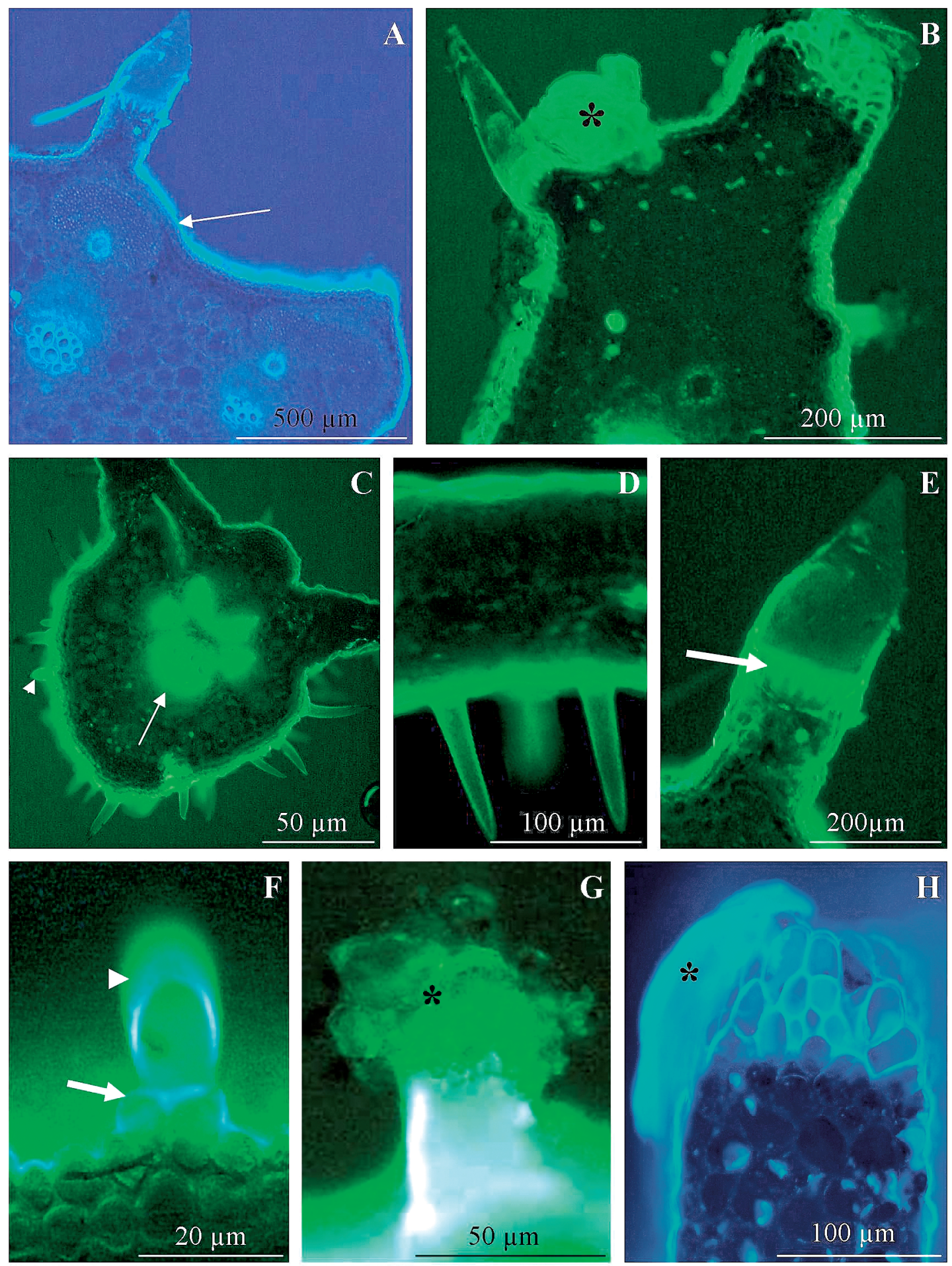

Fig. 3 A-H. Fragments of H. sosnovskii stem (A) and leaves (B-H) (cross section) after treatment with auramine $\mathrm{O}$ and with the use of DAPI (A, H) or TRIC (B-G) filters (fluorescence microscope):

A, B - stem (A) and petiole (B) tissues, visible light blue fluorescence of the cuticle (DAPI), green fluorescence of epidermal cells, the base of the trichomes and secretion (asterisk),

$\mathrm{C}$ - leaf blade vein with numerous trichomes on the abaxial epidermis; visible fluorescence of epidermal cells and trichomes (arrowhead) and tracheal elements (arrow),

D -leaf blade with trichomes; visible intensely fluorescent cells of the abaxial epidermis,

E, F - trichomes on the surface of the petiole (E) and the abaxial epidermis of the leaf blade (F); visible fluorescent cells of the trichome base (arrow) and subcuticular space (arrowhead),

$\mathrm{G}, \mathrm{H}$-trichomes with liberated secretion (asterisk). 


\section{DISCUSSION}

Coumarins are biologically active substances often contained in essential oils. Furanocoumarins are lipophilic coumarins that easily sublimate or are volatile with water vapour and make up essential oils. Psoralen-type furanocoumarins are common in plants from the families Apiaceae and Rutaceae and the genus Psoralea (Fabaceae). Psoralen is a furanocoumarin exerting a strong phototoxicity effect on humans $[17,18]$.

Investigations carried out by other authors demonstrate that Heracleum furanocoumarins are contained in trichomes present on the plant leaves and stems [7]. In a related species $H$. mantegazzianum, the highest concentration of furanocoumarins was detected in fruits, an intermediate content was found in leaves, while stems exhibited the lowest concentration [5].

Our research shows the highest density of trichomes on the abaxial surface of the leaf blades and on the petioles in $H$. sosnovskii. The viable, unicellular trichomes release a secretion visible on their surface and deposited on the walls of adjacent epidermal cells. The secretion observed in microscope preparations is foamy or crystalline, which may be related to its ability to sublimate, as mentioned by Kohlmünzer [18] in the characterisation of furanocoumarins.

The fluorescence microscope showed strong fluorescence of the cuticle on the epidermal cells and secretion deposits on the surface of trichome walls. When the FITC filter was used, the epidermal cells of the leaf blade and petioles emitted green fluorescence. It can be assumed that the fluorescence of the secretions produced by the $H$. sosnovskii leaf trichomes is produced by the presence of furanocoumarin, since coumarin solutions exhibit strong fluorescence, as reported by Koh $1 \mathrm{mün} z$ e r [18]. The intense fluorescence of the leaf epidermal cells is probably related to the presence of secretion, which has the ability to emit fluorescence. The strong fluorescence of the internal tissues of $H$. sosnovskii leaves may be associated with the substantial content of furanocoumarins, which was also found by $\mathrm{Pir}$ a et al. [5] in H. mantegazzianum leaves.

The morphological diversity of trichomes occurring on the surface of the $H$. sosnowskii stem and leaf epidermis corresponds with the results obtained by several authors, who have described different types of trichomes in other Heracleum species [14, 15].

\section{Acknowledgments}

This research was supported by the Ministry of Science and Higher Education of Poland as a part of the activities of the Department of Botany, University of Life Sciences in Lublin.

\section{Authours' contributions}

Concept of the study: EW-C; microscopical analysis: EW-C, MC; writing of the manuscript: EW-C, $\mathrm{MC}$, photographs: MC.

\section{REFERANCES}

1. Podbielkowski Z, Sudnik-Wojciechowsk a B. Słownik roślin użytkowych. Warsaw: Państwowe Wydawnictwo Rolnicze i Leśne; 2006.

2. Tokarska-Guzik B, Dajdok Z, Zając M, Zając A, Urbisz A, Danielewicz W, Hołdyński Cz. Rośliny obcego pochodzenia w Polsce ze szczególnym uwzględnieniem gatunków inwazyjnych. Warsaw: Generalna Dyrekcja Ochrony Środowiska; 2012.

3. Miklas zewska K. Barszcz Sosnowskiego - obcy gatunek inwazyjny: biologia, zagrożenia, zwalczanie. Prog. Plant Protection 2008, 48(1): 158-160.

4. Kavli G, Midelfart K, Volden G, Krokan $\mathrm{H}$. Photochemical reactions of Heracleum laciniatum. Influence of dimethyl sulphoxide and corticosteroids. Br. J. Dermatol. 1983, 109, Suppl 25:137-140. http://dx.doi. org/10.1111/j.1365-2133.1983.tb06826.x

5. Pira E, Romano C, Sulotto P. Heracleum mantegazzianum growth phases and furocoumarin content. Contact Dermatitis. 1989, 21(5): 300-303. http://dx.doi. org/10.1111/j.1600-0536.1989.tb04747.x

6. Lagey K, Duinslaeger L, Vanderkelen A. Burns induced by plants. Burns 1995; 21(7): 542-543. http://dx.doi.org/10.1016/0305-4179(95)00026-8

7. Jakubowicz O, Żaba C, Nowak G, Jarmuda $\mathrm{S}$, Żaba R, Marcinkowski JT. Heracleum sosnowskyi Manden. Ann. Agric. Environ. Med. 2012; 19, 2: 327-328.

8. Kucharczyk M. Distribution atlas of vascular plants in the Middle Vistula Rive Valley. Rozprawa habilitacyjna. Lublin: Maria Curie-Skłodowska University Press; 2001.

9. Zając A, Zając M. Atlas rozmieszczenia roślin naczyniowych w Polsce. Krakow: Pracowania Chorologii Komputerowej Instytutu Botaniki UJ; 2001.

10. Rutkowski L. Klucz do oznaczania roślin naczyniowych Polski niżowej. Warsaw: Polish Scientific Publishers PWN; 2006.

11. Piwowarski B. Maciejczak B. Rozmieszczenie i tendencje rozprzestrzeniania się Heracleum mantegazzianum Sommier \& Levier [H. sosnowskyi Manden.] na Płaskowyżu Jędrzejowskim i terenach przyległych (Wyżyna Małopolska). Program LV Zjazdu Polskiego Towarzystwa Botanicznego. Planta in vivo, in vitro et in silico. September 6-12. Warsaw: Polskie Towarzystwo Botaniczne - Zarząd Główny; 2010: G120.

12. Śliw ińs k i M. Barszcz Sosnowskiego-Heracleum sosnowskyi Manden. i barszcz Mantegazziego - Heracleum mantegazzianum Somm. et Levier. In: Dajdok Z, Pawlaczyk P, editors. Inwazyjne gatunki roślin ekosystemów 
mokradłowych Polski. Świebodzin: Wydawnictwo Klubu Przyrodników; 2009: 54-57.

13. Sa dowska A. 2004. Rakotwórcze i trujące substancje roślinne. Warsaw: University of Life Sciences Press; 2004.

14. Arora K, Grace J, Stewart F. Epidermal features of Heracleum mantegazzianum Somm. \& Lev., H. sphondylium L. and their hybrid. Bot. Journal Lin. 1982, 85(3): 169-177. http://dx.doi.org/10.1111/j.1095-8339.1982.tb02584.x.

15. Liu HaiYan, Yu Yan, Deng Xian Lan, He $\mathrm{Xing}$ Jin. Leaf epidermal morphology and systematic significance of genus Heracleum in Southwest China. Acta Bot. Bor.-Occid. Sin. 2009; 29(9): 1833-1845.

16. Szweyk ows cy A, J. Słownik botaniczny. Warszawa: Wiedza Powszechna; 2003.

17. Knudson EA, Kroon S. In vitro and in vivo phototoxicity of furocoumarin-containing plants. Clin Exp Dermatol. 1988; 13(2): 92-96. http://dx.doi.org/10.1111/j. 1365-2230.1988.tb00666.x.

18. Kohlmünzer S. Farmakognozja. Podręcznik dla studentów farmacji. Warsaw: Wydawnictwo Lekarskie PZWL; 2013.

\section{Struktury łodyg i liści Heracleum sosnovskii Manden. emitujące substancje wywołujące fotodermatozy}

\section{Streszczenie}

Heracleum sosnovskii Manden. zawiera w łodygach i liściach furanokumaryny, które mają właściwości fototoksyczne dla człowieka. Celem badań było określenie budowy zewnętrznych struktur wydzielniczych występujących w epidermie oraz wewnętrznych tkanek wydzielniczych położonych w wymienionych organach, które mogą być odpowiedzialne za emisję toksycznej dla skóry wydzieliny. Do badań zastosowano mikroskopię świetlną oraz fluorescencyjną. Stwierdzono, że w łodygach i liściach występują różne typy włosków wydzielniczych, na których powierzchni zaobserwowano rozproszoną lub tworzącą złogi wydzielinę. Najwięcej włosków znaleziono na powierzchni abaksjalnej liści. Komórki epidermy oraz obecna na zewnątrz włosków wydzielina wykazywały intensywną fluorescencję, co może wskazywać na obecność furanokumaryn w tej tkance oraz w wydzielinie włosków.

Handling Editor: Elżbieta Pogroszewska

This is an Open Access digital version of the article distributed under the terms of the Creative Commons Attribution 3.0 License (creativecommons.org/licenses/by/3.0/), which permits redistribution, commercial and non-commercial, provided that the article is properly cited.

CThe Author(s) 2014 Published by Polish Botanical Society 
